\title{
Alban Berg'in Wozzeck Operası Hakkında Tarihsel Bir İnceleme
}

\author{
DOI: 10.26466/opus.574108
}

\begin{abstract}
$*$
\section{$\underline{\text { R. Görkem Aytimur* }}$}

*Dr. Öğr. Üyesi, Tokat Gaziosmanpaşa Üniversitesi, Eğitim Fakültesi, Tokat / Türkiye E-Posta: gorkemaytimur@gmail.com ORCID: 0000-0001-8389-1504
\end{abstract}

\section{Öz}

Bu çalışmada Alban Berg'in ilk operası olan Wozzeck hakkında tarihsel bir inceleme gerçekleştirilmiştir. 20. yy'ın ilk yillar itibariyle avant-garde ve ekspresyonist (dışavurumcu) bir müzik dilinin önemli örneklerinden biri olan Wozzeck operası, atonal müziğin gelişmesinde de bir yapı taşı niteliğindedir. Henüz kurumsal anlamda şekillenmemiş oniki ton sistemini önceleyen süreçte, tonal-atonal müzik dönüşümü anlamında Berg'in ustaca çözümler üretmesi, eserin öneminin bir kez daha altını çizmiştir. Tarihsel niteliği göz önünde bulundurularak, operanın bu bağlamda incelenmesi de çalışmanın önemi ifade etmektedir. Çalışmada Wozzeck'in, tiyatro metninden librettoya uyarlanması ile bestelenme ve temsil edilme süreçleri incelenmiştir. Operantn müziksel ve dramatik anlanmadaki avand-garde dili, bestelendiği günden bu yana birçok tartışmanın odă̆ olmuştur. Özellikle Nazism'in bütün bir Avrupa'yı etkilediği yıllarda, operanın bu sıra dışı yapısı birçok eleştiri ve yasağı da beraberinde getirmiştir. Böylece söz edilen bu sosyo-politik koşulların da incelenmesi, çalışmanın başka bir yönünü açığa çıkarmıştır. Bütün bu kavramsal çerçevelerin yanında, incelemenin bütünlüğ̈̈ gereği eserin müzikal yapısından ve konusundan da söz edilmiştir. Bununla birlikte esas amaçlanan, operanın 20. yy müziği içindeki tarihsel öneminin belirtilmesidir.

Anahtar Kelimeler: $\quad$ Wozzeck, Alban Berg, George Büchner, Atonalite 


\title{
A Historical Review About Alban Berg's Wozzeck
}

\begin{abstract}
In this study, a historical examination was made about Wozzeck, the first opera of Alban Berg. The Wozzeck opera, which is an important example of an avant-garde and expressionist music language in the early years of the 20th century, is a building block for the development of atonal music. Berg's ingenious solutions in terms of tonal-atonal music transformation underlined the importance of the work once again in the process that preceded the twelve-tone system, which has not yet been institutionalized. Considering the historical quality, the study of opera in this context expresses the importance of the study. In this study, Wozzeck's adaptation from theatrical text to libretto and its composition and representation processes are examined. The avand-garde language of the opera's musical and dramatic understanding has been the focus of many discussions since its composition. Especially in the years when Nazism influenced a whole Europe, this unusual structure of opera brought many criticisms and prohibitions. Thus, the examination of these socio-political conditions revealed another aspect of the study. In addition to all these conceptual frameworks, the musical structure and synopsis of the work is mentioned in accordance with the integrity of the study. However, the main aim is to emphasize the historical importance of opera in 20th century music.
\end{abstract}

Keywords: Wozzeck, Alban Berg, George Büchner, Atonality 


\section{Giriş}

Bu çalışmada Alban Berg'in Wozzeck operasının özgün yapısı, tarihsel bağlamda ele alınmıştır. Çalışmanın kavramsal bütünlüğü açısından eserin müzikal dilinden ve konusundan da söz edilmiştir ancak, temel olarak tarihsel süreç içinde operanın koşullarına odaklanılmıştır. Böylece 20. yy operaları içinde Wozzeck'in yeri ve önemi ifade edilmek istenmiştir.

Wozzeck Avusturyalı besteci Alban Berg'in ilk operasıdır. 1914-1922 yılları arasında yazılmıştır. Opera ilk kez 1925 'te sahnelenmiştir. Opera metni, Alman oyun yazarı George Büchner'in yazdığı bir drama olan Woyzeck'ten alınmıştır.

Berg'in Wozzeck'i, 20. yy'ın ilk yarısında bestelenen en önemli operalardan biridir. Özellikle Wagner sonrası opera repertuarındaki yeri açısından da önemi büyüktür. Avrupa opera endüstrisinde birçok opera kurumunun repertuar seçimleri, 18 ve 19. yy operalarının izleyici çekeceği kesin olan klasik eserleri tercih etme yönündedir. Bu opera kurumlarının repertuarlarına giren 20. yy operaları da çoğunlukla geleneksel bir müzik dili kullanılan örneklerden seçilmektedir. Bu anlamda Alban Berg'in operaları bu konuda istisna niteliğindedir. Alban Berg'in iki operası da (Wozzeck ve Lulu), radikal bir müziksel dile sahip oldukları halde, hem söz edilen bu repertuarlara alınmış, hem de sanatsal güçlerini ilk sahnelendiği günden bugüne korumuşlardır. Jarman'a (1989) göre, Wozzeck, atonal bir müzik örneğidir ancak, günümüzde neredeyse 'klasikleşmiş' bir eser olarak, 20. yy operaları repertuarındaki yerini korumaktadır. Bu konuda besteci, eseri hakkında şöyle söylemektedir:

Wozzeck'le opera tarihinde bir deorim yapmayı asla düşünmedim. Amacim sadece iyi bir müzik meydana getirmek olmuştur. Tiyatroya hakkı olan şeylerden fazlasını vermeğe kalkmak aklımdan geçmedi. Dramı gerçeğe ulaştırmak için müziğimi bazı elemanlarla güçlendirmeye çalıştım. Bunlar da hiçbir vakit müzik dışı şeyler değildir. Antik şekilleri kullanışımın amacı ise perdenin açılışından kapanışına kadar geçen süre boyunca dinleyiciyi birbirini izleyen dalgalarla sürüklemek içindir (Berg'den aktaran Yener, 1992, s.424). 
Wozzeck, Berg'in ilk sahne eseridir Bir başka bestecinin eserlerinin performanslarını görerek edindiklerinden başka hiçbir tiyatral deneyimi olmadan, ustaca bir kavrayışla müzikal yapıyı ve dramatik hareketliliği bir araya getirdiği, özgün bir eserdir. Berg, Wozzeck'in müziksel tasarımında, 20. yy'ın değişen sanat dünyanın talep ve isteklerine ustaca ve özgün bir şekilde çözümler sunmuştur. Diğer taraftan Berg'in bu bakış açısı daha sonraki besteciler için bir model haline de gelmemiştir. Bunu temel sebebi Berg'in, Wozzeck'teki müzikal formlar ile dramatik hareketlilikler arasındaki ilişkiyi kurulma şeklinin ona özgü oluşudur.

Wozzeck, o zamana kadar hiçbir sahneleme biçimi için uygun görülmeyen, zihinsel ve duygusal anlamda deneysel çalışmalar barındırmaktadır. Bu bakımdan da tiyatro repertuarı içinde radikal bir konumu temsil eder. Karakterlerin deliliğe varan nevrotik geçişleri ve bu durumları sahnede kullanmaya yönelik müzikal ve dramatik çözümler, 19. yy'ın sonlarındaki başka operalarda da görülmektedir. Fakat hiçbir opera Wozzeck gibi, psikolojik derinliği bu denli karmaşık bir "anti-kahraman" karaktere sahip değildir. Bu anlamda Wozzeck karakterinin zihinsel dengesizliğini göstermedeki etkisinin seyirci tarafından algılanması, daha önce hiçbir operada olmadığı kadar güçlüdür.

20. yy'ın ilk yıllarında, sanatın dışavurumcu (ekspresyonist) dili, aşırı zihinsel ve duygusal durumları ifade etmekte uygundur. Jarman'a (1989) göre, sanatçının bir duygudaki nevrotik açlımları göstermek için gerçekliği bilinçli olarak dönüştürdüğü sanatsal bir hareket olan dışavurumculuk, 1910-20'li yıllarda Almanya ve Avusturya'daki sanat dünyasına etkisi altına almıştır. Almanya'da dışavurumculuğun yerleşik bir sanat akımı haline gelmesinden yaklaşık 75 yıl önce yazılmış olmasına rağmen, Büchner'in Woyzeck'i, dişavurumculuğun birçok özelliğini barındırmaktadır. Büchner bu oyununda gerçekliği başka bir açıyla ele alınmış ve dönüştürülmüştür. Her şey garip, fantastik, karanlık ve puslu bir atmosfere içkindir. Oyunda söz edilen her şeyin görünürlüğünün arkasında bir başka anlam, uzantı vardır ve bu tüm gerçekliğin garipleşmesine neden olmaktadır. Jarman'a (1989) göre, Büchner'in Woyzeck karakterinin yaşadığı karanlık ve vurdumduymaz dünya, Herbert Read'in "insanın düşmanca ve insanlık dışı bir doğanın varlığında hissedebileceği huzursuzluk ve terör" dediği şeyi yansıtmaktadır. 
Berg'in operasının güçlü dramatik etkisinin nedeni, seyirciyi Wozzeck'in kritik anlarında yaşadıklarını deneyimlemeye ve onun dünya ya ilişkin korkunç halüsülasyonlarını hissetmeye zorlanmasından kaynaklanmaktadır. Fakat Wozzeck'te gördüğümüz şey, sade bir zihnin yansıması değildir. Aynı zamanda sadece aldatılmış bir kişinin ve duygusuz bir toplumun resmi de değildir. Hem toplumsal düzene, hem de müzikal yapının açıkça belirttiği gibi, dünyanın doğasına nevrotik bir karşı duruştur.

Berg'in operası da bize enformatif bir gerçekçilikten çok 'yükseltilmiş ve çarpıtılmış' bir gerçeklik sunmaktadır. Wozzeck'te, baş karakterin insanların günlük işleriyle uğraştıkları ve sıradan hayatlarını sürdürdükleri normal bir toplum içindeki bir "uyumsuz" olarak gösterilme çabası yoktur. Berg'in anlatımında toplum, bencil ve sadist bir egemen sinıfin, yoksul olanlara karşı maddi tahakkümleri ve boş ahlaki dayatmalarıla yapılanmış, zaten çarpık bir düzendedir. Bu toplum Wozzeck gibilerin kaçınılmaz olarak yoksul olduğu, acl çektiği ve bir suçluya dönüştüğü insanlık dışı ve çirkin bir yerdir. Ancak perde kapandığında, Wozzeck öldüğünde veya opera sona erdiğinde; yani müzik sahnedeki karakterlerden ve olaylardan çıkarıldığında operada bir insanlık unsuru hissedilmektedir (Jarman, 1989, s.2).

Berg'in müzikal anlayışındaki dışavurumcu anlatımı, tonalite ve atonalite sınırındaki ifade gerginliğini sürekli kullanan bir müziksel yap1 olarak, Wozzeck'in psikolojik durumunu göstermenin çok uygun bir yolu haline gelmiştir. 20. yy'ın ilk on yılının müziksel anlayışı, Wozzeck gibi bir karakterin dengesiz ruh halini ifade etmekte eksik kalmaktadır. Öte yandan, İkinci Viyana Okulu bestecileri, 1925'ten sonraki yıllarda, yeni bir müziksel yapının yaratılması için daha sistematik bir yaklaşım geliştirmişlerdir. Bununla birlikte Berg zaten, operasındaki baş karakteri olan Wozzeck'in psikolojisini ifade etmek için bu müziksel dili çoktan etkili bir şekilde kullanmıştır.

Çalışmanın bu aşamasında George Büchner'in "Woyzeck" isimli dramasının Alban Berg'in "Wozzeck" operasına nasıl dönüştürüldüğü tarihsel bağlamda ele alınacaktır. 


\section{Büchner'in Woyzeck'inden Berg'in Wozzeck'ine}

Büchner, 19 Şubat 1837'de 23 yaşında öldüğünde, başyapıtı Woyzeck'in parça taslakları da dahil olmak üzere birçok eseri geride bırakmıştır. 1850 yılanda, yazarın eserlerinin yayınlandığı bir edisyonda basılmıştır. Ancak bu çalışmada Woyzeck oyunu yer almamıştır. Bunun en temel sebebi oyunun bazı yerlerindeki müstehcenliktir. Ayrıca metin tam tamamlanmamış ve yazarın el yazısı da tam çözümlenememiştir.

Büchner öldüğünde, Woyzeck'in tamamlanmamış el yazmaları bazı karışıklıklara neden olmuştur. Bu karışıklık günümüzde, mevcut olan metnin basılı versiyonlarında orijinal metinlerden herhangi bölümün çıkarılıp çıkarılmadığı konusunda, hala devam etmektedir. Hepsinden daha da sorunlu olan konu ise, oyunun Woyzeck'in yargılanmasını ve idam edilmesini içerecek şekilde genişletilip genişletilmeyeceğidir. Gerçek olaylara dayanan bu oyunun asıl hikayesinde, metresini (Johanna Christiane Woost'u) öldürüldügü için Johann Christian Woyzeck, 27 Ağustos 1824'te idam edilmiştir. Karl Emil Franzos'un 1879'da yayınladığı ilk versiyonda önemli bir not bulunmaktadır. Franzos'un oyunun sahnelenmesi ile ilgili yazdığı yönlendirme notlarında, boğulma meselesiyle ilgili kanıt olacak, Brücner'e ait bir el yazısı olmadığını belirtmiştir.

Leipzig Mahkemesi'nin isteği üzerine psikiyatrist Dr. Hofrat Clarus tarafından Johann Christian Woyzeck'e bir psikolojik çalışma yapılmış ve iki rapor (1821/1823) hazırlanmıştır. Bu konu, Giessen'de tıp öğrencisi olan, daha sonra Zürih Üniversitesi'nde doğa bilimleri konusunda öğretim görevlisi olarak çalışan ve doktora tezini karşılaştırmalı anatomi alanında yapan Büchner'in ilgisini çekmiştir. Konunun ilgi çekici yanı, Woyzeck'in psikolojik durumu nedeniyle cinayetle sonuçlanan hareketlerinden sorumlu olup olamayacağıdır. Dr. Clarus'un hazırladığı raporlarda Woyzeck yaşanan olaylar karşısında sorumlu bulunmuştur. Bunun sonucunda Woyzeck'in infazının önünü açılmıştır. Bu olay, dönemin psikiyatri dünyasının içinde bir tartışma konusuna dönüşmüştür.

Bütün bu olayları yakından takip eden Büchner, Woyzeck'i oyun metni olarak ele almaya karar vermiştir. Böylece Woyzeck, düz yazı şeklinde yazılmış ve sıradan bir adamın baş kahraman olarak gösterildiği, "düşük" yaşam tarzını yansıtan bir dramaya dönüşmüştür. 
Büchner'in dramında insan doğa önemli bir rol oynamaktadır. Ona göre, insan doğasının derinlerinde yatan hayvansal unsurlarla ahlaklı veya akılcı davranışlar arasında hassas bir sınır bulunmaktadır. Bu unsur ya da davranışlar insanın sadece bir görünümünü ifade etmektedir. Bir anlık travma insanın bu doğasını tersine çevirebilmektedir. "Büchner, Woyzeck'in deliye dönüşümünü insan varoluşunun kaçınılmaz sonucu olarak göstermektedir" (Reich, 1932, s.2).

Oyunda da Woyzeck için bu travmatik kırılma anı, metresi olan Marie'nin, Bando Şefi'yle yaşadığı ilişkiyi öğrenmesi olarak ifade edilmektedir. Doktorun onun üzerinde yaptığı deneyinin yan etkileri ve üstüne de metresi Marie'nin onu aldatması Woyzeck'i tetiklemiştir. Ahlaki veya akılcı olan ile içgüdüsel olan arasındaki ince çizginin üzerine itilmiştir. Akıl ve delilik arasındaki çizgide Woyzeck deliye dönüşmüştür. Ancak Woyzeck'in "deliliği”, kötü ve paranoyak Doktor ve Kaptan'ınkinden daha üstün bir şekilde, insan doğasının işleyişi üzerine net bir fikir vermektedir. Uyumlu ve estetikle yapılanmış bir yaklaşım yerine, karakterlerin psikolojik anlamda kasvetli, belirsiz, akıl dışı, patolojik yanları vurgulanarak, insan doğasının dönüşümü belirtilmiştir. Woyzeck'in dönüşümüyle birlikte uçurum apaçık görünür olmuştur.

On yıllar sonra, editör Karl Emil Franzos, unutulmuş ve neredeyse okunaklı olmayan el yazmalarına ışık tutmaya çalışmıştır. Böylelikle, 1879'da Büchner'in Woyzeck'inin parçalarının düzenlenmiş bir versiyonunu yayınlamıştır. Parça parça bölümleri kendince uygun gördüğü sıraya göre düzenlemiştir. ${ }^{1}$

Drama, modern oyun yazarlığının gelişimi üzerinde büyük bir etkiye sahip olmuştur. Bununla birlikte Woyzeck 1913'e kadar sahnelenmemiştir. Georg Büchner'in Woyzeck'i 1913'te Münih'te sahnelenmek üzere hazırlandığında Ekspresyonist çevreler tarafından büyük bir coşkuyla yeniden keşfedilmiştir. Bu Naturalist ve Ekspresyonist yazar ve sanatçlar, oyunda beklentilerinin çoğunu bulmuşlardır.

\footnotetext{
${ }^{1}$ Bu süreçte Franzos, tarihsel bir hata yapıp, yanlışıkla oyunun adını ve kahramanını Wozzeck olarak değiştirmiştir. Berg bu edisyondan hareket ederek eserinin librettosunu hazırladığından, operanın ismi de Wozzeck olarak kalmıştır.
} 
Alban Berg, 5 Mayıs 1914'te, Viyana'daki ilk temsile katılmış ve bu dramadan bir opera bestelemeye karar vermiştir. Büchner'ın kabataslak tasarımı, tamamen yeni bir dramaturjik uygulamayı gerekli kılmıştır. Büchner'in oyunundan geriye 25 sahne kalmıştır. Berg, bu sahnelerden 15 'ini seçmiş ve her biri 5 sahneden oluşan 3 perdelik bütünlüklü bir yap1 kurmuştur. Operanın librettoyu kendi uyarlamıştır.

Berg'in dramaturjisi malzemeyi yoğunlaştırmakta ve netleştirmektedir. Illk önce onu üç bölüme ayırır: Giriş (açıklama), gelişme (olaylarm gelişimi - sadakatsizlik) ve felaket. Oyun metni üzerinde yaptığı ufak değişiklikler sayesinde, bireysel sahneleri simetrik ve orantılı bir şekilde gösterir ve böylece iyi tasarlanmış, dengeli bir drama dönüştürür (Reich, 1932, s.4).

Operanın kurgulanışında askerlerin günlük yaşamı ve Almanca konuşulan bir kasaba ve halkının yaşantısı gösterilmektedir. Militarizm, duyarsızlaşma, sosyal sömürü ve sadizmin öne çıkan temalar olarak vahşice ve sert bir dille sunulmuştur. Müzikolog Glenn Watkins'a göre, operanın özellikle baş karakteri olan Wozzeck'in sözlerinde II. Dünya Savaşı'nın imaları bulunmaktadır.

Berg Wozzeck'i bestelediği süreçte oyunun temel düşüncesiyle karşı karşıya kalmıştır: Insan bir uçurumdur. Bu, kaçınılmaz trajik bir ilerleyişte baş kahramanın (belki de anti-kahramanın demek daha uygundur) psikolojik dönüşümünde, aldatıcı halüsinasyonlar ile gerçeklik iç içe geçmiştir (Sandu-Dediu, s. 52).

Büchner, final için geriye birkaç farklı dramatik sahne alternatifi bırakmıştır. Bunlar: Woyzeck işlediği suçtan ötürü yakalanır ve yargılanır (Büchner'in hikayesini temel aldığı olayların tarihi gerçekliğiyle bu son eşleşmektedir.); Woyzeck, Marie'yi öldürmek için kullandığı bıçağı bulmaya çalışırken boğulur. Bu aşamada senaryo, iki olası duruma ayrılmaktadır: Woyzeck ya intihar etmiştir ya da cinayet silahını, attığı gölette bulmaya çalışırken boğulmuştur. Baş kahramanın ölümüyle ilgili bu belirsizlik aynı şekilde Berg'in operasında, sondan bir önceki sahnede görülmektedir. Son bölümdeki orkestra interlütü (D Minör invansiyon), izleyicinin/dinleyicinin dikkatini yalnızca müziğe odaklar. Berg, operadaki tüm önemli olayların özetini müzikal filmi dizisi olarak tasarlar ve sadece duyuma yönelerek, hayal gücünü zorlar. Bu aşamada artık tüm temel motifler, Schoenberg'in tekniğini hesaba katmayacak bir sirayla 
tekrarlanır. Burada Berg, açık bir şekilde, D Minor veya D Major tonalitede, Gustav Mahler' in geleneksel senfonik anlayışına dönmüştür. Bu senfonik şiir bölümünden sonra operanın perdesi kapanır fakat, perde geri açılır ve Wozzeck ve Marie'nın çocuğunun, arkadaşlarıyla birlikte gösterildiği sahne gelir. Diğer çocuklar, Wozzeck ve Marie'nın oğluna göletin kıyısında annesinin ölü bulunduğunu söylemektedirler. O ise masumca oyuncak atıyla oynamaktadır. Berg, çocuğun bütün gerçeklikten uzak dünyasını yansıtmak için sağduyulu, tekrarlara dayanan, göz alıcı orkestranın neredeyse sonsuz hareketiyle genişletilmiş ve kademeli bir şekilde sessizliğe doğru yol alan bir müzikal anlatıma dayalı bir final oluşturmuştur.

Bununla birlikte, finale kadar, besteci açıkça Büchner'ın parça parça olan sahneleri takip etme etmiştir. Operayı her biri beş sahne olacak şekilde, üç perdede (konunun anlatıldığı klasik bir giriş, konunun gelişimi ve felaket ve kırılma) yapılandırır. Yirmi üç konuşma rolü olan karakter vardır. Oyun ve opera libretto arasındaki diğer farklıliklar Berg'in sahne araçların kullanma konusundaki ekonomik yaklaşımıdır. Besteci, örneğin hayvanların oyunda kullanımın içeren sahnelere hem sahne üzerindeki kullanımındaki zorluklardan, hem de dramatik çatışma üzerinde bir etkileri olmadiğından dolayı, operasında yer vermemiştir. Bununla birlikte hayvanların sahne üzerinde kullanilmasiyla dramatik anlamda gergin bir atmosferin yaratılması konusunu ihmal etmiş, bu etkiyi müzikle sağlamıştır. Ayrıca oyundan operaya dönüşümde iç yapıların düzenlenmesi konusu, asgari düzeyde tutulmuştur. Bu nedenle Berg'in, eserinin kaynağına ve yazarının edebi yeteneğine saygıyla yaklaşan bir besteci olduğunu söylemek mümkündür (Sandu-Dediu, s. 53).

Diyaloglar çoğunlukla Büchner'in orijinal metindeki gibidir. Opera'nın ilk sahnesi, oyunun neredeyse aynısıdır (Kaptan'ın sondan bir önceki cümlesi dışında). Aynı şekilde, operanın 1., 2., 3., 5. sahnelerine karşılık gelen, oyunun 2., 3., 7., ve 8. sahneleri ve operanin 2. perdesindeki 2., 3., 4. sahnelerine karşılık gelen oyunun 6., 9., 10. ve 12. sahneleri neredeyse aynıdır. Operada, 2. perdenin 5. sahnesi, oyunun 14. ve 17. sahneleridir. Son olarak, besteci oyundaki 19. (deli adamın konuşmaları hariç), 22., 23. (Kathe libretto'da Margret olmuştur) ve 24. (Doktor ve Kaptan 
oyundaki birinci ve ikinci adamın yerine geçiyor) sahneleri, operada 3 . perdenin 1., 2., 3. ve 4 . sahneleri olarak düzenlemiştir. Final ise, tamamen besteciye aittir.

Büchner' in draması ile Berg'in operasının sahnelerinin karşılaştırılmalı düzeni şöyledir:²

\begin{tabular}{|c|c|}
\hline $\begin{array}{l}\text { Woyzeck: Büchner } \\
\text { (Franzos / Landau) }\end{array}$ & Wozzeck: Berg \\
\hline & 1. PERDE \\
\hline $\begin{array}{l}\text { 1. Sahne } \\
\text { Bir oda } \\
\text { Woyzeck Kaptanı tıraş etmektedir. }\end{array}$ & $\begin{array}{l}\text { 1. Sahne } \\
\text { Kaptan'ın odası } \\
\text { Sabahın erken saatleri } \\
\text { Wozzeck Kaptanı tıraş etmektedir. }\end{array}$ \\
\hline $\begin{array}{l}\quad \text { 2. Sahne } \\
\text { Şehirden uzak, kırsal bir yer } \\
\text { Woyzeck ve Andres ağaçları budamakta ve otları } \\
\text { kesmektedirler. }\end{array}$ & $\begin{array}{l}\text { 2. Sahne } \\
\text { Şehirden uzak, kırsal bir yer }\end{array}$ \\
\hline $\begin{array}{l}\text { S. Sahne } \\
\text { Şehirde bir yer } \\
\text { Marie odasının dışındaki askeri geçit törenini izle- } \\
\text { mektedir. Çocuğuna şarkı söyler. Bu sırada } \\
\text { Woyzeck gelir. }\end{array}$ & $\begin{array}{l}\text { Marie'nin odası. } \\
\text { Güneşli bir sabah }\end{array}$ \\
\hline $\begin{array}{l}\text { 4. Sahne } \\
\text { Doktorun çalışma odası } \\
\text { Doktor Woyzeck'i muayene etmektedir. }\end{array}$ & $\begin{array}{l}\text { 4. Sahne } \\
\text { Doktorun çalışma odası } \\
\text { Güneşli bir öğleden sonra }\end{array}$ \\
\hline $\begin{array}{l}\text { 5. Sahne } \\
\text { Açıkhava bir yer } \\
\text { Marie ve Woyzeck bir fuarı gezmeye gitmişlerdir. }\end{array}$ & \\
\hline $\begin{array}{l}\text { 6. Sahne } \\
\text { Stantlardan birinde Marie ve Woyzeck eğitimli bir } \\
\text { eşek gösterisi izlemektedirler. }\end{array}$ & \\
\hline $\begin{array}{l}\text { 7. Sahne } \\
\text { Sokak } \\
\text { Bando Şefi Marie'yi baştan çıkartır. }\end{array}$ & $\begin{array}{l}\text { 5. Sahne } \\
\text { Marie'nin odasının önündeki sokak } \\
\text { Akşam karanlığı }\end{array}$ \\
\hline \multicolumn{2}{|l|}{$\begin{array}{l}\text { 8. Sahne } \\
\text { Doktor'un bahçesi } \\
\text { Doktor, bir grup öğrenciye ders vermektedir. }\end{array}$} \\
\hline & 2. PERDE \\
\hline $\begin{array}{l}\text { 9. Sahne } \\
\text { Marie'nin odası } \\
\text { Marie Bando Şefi'nin verdiği küpelere hayran } \\
\text { olmuştur. Woyzeck bu durumu fark eder. }\end{array}$ & $\begin{array}{l}\text { Marie'nin odası } \\
\text { Güneşli bir sabah }\end{array}$ \\
\hline $\begin{array}{l}\text { 10. Sahne } \\
\text { Sokak } \\
\text { Doktor ve Kaptan, Woyzeck ile karşılaşmışlardır. } \\
\text { Marie'nin onu aldattığını ima edip, alay ederler. }\end{array}$ & Şehirde bir sokak \\
\hline
\end{tabular}

${ }^{2}$ D. Jarman, 1989, s.12-15 


\begin{tabular}{|c|c|}
\hline $\begin{array}{l}\text { Marie'nin odası } \\
\text { Woyzeck Marie' yle yüzleşir. }\end{array}$ & $\begin{array}{l}\text { 3. Sahne } \\
\text { Marie'nin odasının önündeki sokak } \\
\text { Bulutlu bir gün }\end{array}$ \\
\hline \multicolumn{2}{|l|}{$\begin{array}{l}\text { Bekçi odası Sahne } \\
\text { Woyzeck ve Andres }\end{array}$} \\
\hline $\begin{array}{l}\text { 13. Sahne } \\
\text { Taverna } \\
\text { Woyzeck, Marie'nin Bando Şefi'yle dansını izler ve } \\
\text { bu durum karşısında kontrolsüzce hareket eder. }\end{array}$ & $\begin{array}{l}\text { 4. Sahne } \\
\text { Bir tavernanın bahçesi } \\
\text { Akşam geç bir saat }\end{array}$ \\
\hline $\begin{array}{l}\text { Kırsal bir yer } \\
\text { Gece } \\
\text { Woyzeck sesleri ve müziği duyar. }\end{array}$ & $\begin{array}{l}\text { 5. Sahne } \\
\text { Askeri bölgede bir koğuş } \\
\text { Gece }\end{array}$ \\
\hline $\begin{array}{l}\text { 15. Sahne } \\
\text { Askeri bölgede bir koğuş }\end{array}$ & \\
\hline \multicolumn{2}{|l|}{ 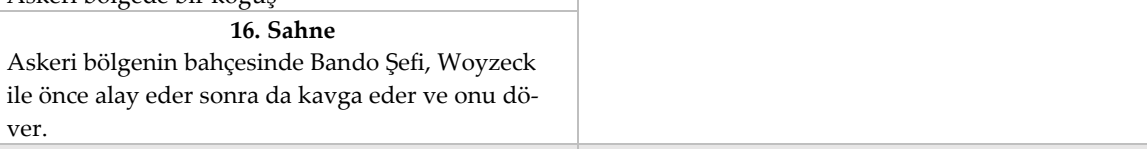 } \\
\hline & 3. PERDE \\
\hline $\begin{array}{l}\text { 18. Sahne } \\
\text { Rehinci } \\
\text { Woyzeck bir bıçak satın alır. }\end{array}$ & $\begin{array}{l}\text { Marie'nin odası } \\
\text { Gece } \\
\text { Mum ışıkları yanmaktadır. }\end{array}$ \\
\hline $\begin{array}{l}\text { 19. Sahne } \\
\text { Sokak. } \\
\text { Güneşli bir öğleden sonra } \\
\text { Marie oynayan çocukları izlemektedir. Yaşlı bir } \\
\text { kadın bir peri masalı anlatmaktadır. }\end{array}$ & $\begin{array}{l}\text { Oyundaki peri masall, operada } 3 \text {. Perde } 1 \text {. sahneye } \\
\text { dahil edilmiştir. }\end{array}$ \\
\hline \multicolumn{2}{|l|}{$\begin{array}{l}\text { 20. Sahne } \\
\text { Askeri bölgede bir koğuş } \\
\text { Woyzeck ceketini Andres'e verir. }\end{array}$} \\
\hline $\begin{array}{l}\text { 21. Sahne } \\
\text { Ormanda, gölet tarafında bir yol } \\
\text { Alacakaranlık } \\
\text { Woyzeck Marie'yi öldürür. }\end{array}$ & $\begin{array}{l}\text { 2. Sahne } \\
\text { Ormanda, gölet tarafında bir yol } \\
\text { Akşam karanlığı }\end{array}$ \\
\hline $\begin{array}{l}\text { 22. Sahne } \\
\text { Bir bar } \\
\text { Woyzeck sarhoş olmayı amaçlamaktadır. }\end{array}$ & $\begin{array}{l}\text { 3. Sahne } \\
\text { Bir bar } \\
\text { Gece } \\
\text { Loş 1şıklı bir ortam }\end{array}$ \\
\hline $\begin{array}{l}\quad \text { 23. Sahne } \\
\text { Ormanda, gölet tarafından bir yol } \\
\text { Gece } \\
\text { Woyzeck boğulur. }\end{array}$ & $\begin{array}{l}\text { 4. Sahne } \\
\text { Ormanda, gölet tarafından bir yol } \\
\text { Mehtaplı bir gece }\end{array}$ \\
\hline $\begin{array}{l}\text { 24. Sahne } \\
\text { Sabahın erken saatleri. } \\
\text { Marie'nin evinin önünde çocuklar oynamaktadır. }\end{array}$ & $\begin{array}{l}\text { 5. Sahne } \\
\text { Marie'nin odasının önü. } \\
\text { Güneşli bir sabah }\end{array}$ \\
\hline $\begin{array}{l}\text { 25. Sahne } \\
\text { Ölünün teşhis edildiği bir oda } \\
\text { Bir doktor ve bir yargıç cinayet hakkında ko- } \\
\text { nuşmaktadır. }\end{array}$ & \\
\hline
\end{tabular}


Bu tür sahne düzenlemeleri bir kenara bırakıldığında, Berg'in, Büchner'in oyunundaki dramatik/müzikal yorumuna ve her karakterin psikolojisinin ana hatlarına sadık kaldığını tekrar belirtmek gerekmektedir. Wozzeck'in Marie ile olan ilişkisi ve çatışması hem trajik hem de halisünatif bir gerginlikle ifade edilmiştir. $\mathrm{Bu}$, belirli bir toplumsal gerçekliği, aynı zamanda tutkular ve halüsinasyonlarla yaşayan bir karakterin "uçurumunu" yansıtmaktadır. Bariton Franz Wozzeck her zaman atonal ve ekspresyonist bir dille şarkı söylerken, karşısında tenor Andres intonal (neredeyse tonal) bir yapıda, onu halüsinasyonlardan kurtarmak ve dünyaya geri getirmek için çabalamaktadır. Marie'nin müziksel yapısı da aynı pragmatik anlayışa sahiptir. Kocasının dengesizliklerinden korktuğu için onun içindeki babalık içgüdüsünü uyandırmayı amaçlar ve tanıdık ninniler söyler. Yine Bando Şefi'ne hayranlığından dolayı da askeri marşlar (bu da neredeysel tonal bir yapıda) söyler. Müzikal söyleminin etkisi, son solosunda, (3. Perde, 1. Sahnede) zirvesine ulaşır. Wozzeck'e ihanet ettiği için pişmanlık duyduğunda, Mary Magdalene'nin İncil'den hikayesini okurken, duygusal olarak Verdi'nin Desdemona'sını hatırlatan bir melodiyi söyler. Diğer karakterlerin her biri grotesk ve egoist dünyalar arasında köprü kurmaktadır. Kaptan, Doktor ve Bando Şefi, dramatik hareketliliğe katılır ve onu katalize ederler. İki sarhoş çırak, Margret ve Marie'in oğlu gerçekliğin parça parça görünümlerini temsil etmektedirler. Deli adam bir çeşit kahindir (tüm tiyatral delilerle benzer özellikte) ve bu nevrotik cinayet hakkında sayıltılarda bulunmaktadır (2. perdedeki meyhane sahnesinin ortasinda).

\section{Berg'in Wozzeck'i Besteleme Süreci}

Berg, 1914 yılında opera üzerinde çalışmaya başlasa da, I. Dünya Savaşı'nın başlamasıyla birlikte er olarak askere gitmiştir. Bu nedenle, 1917'de askeri görevinden ayrılana kadar, çalışmalarına ara vermek zorunda kalmıştır. 1918'de ancak operası üzerine tekrardan yoğunlaşmaya başlayabilmiştir. Berg'in savaş tecrübesi, Wozzeck'in dramatik ve kompozisyon yönleri üzerinde belirgin bir etkiye sahiptir. 1918 yılının haziran ayında karısına yazdığı bir mektupta durumu şu şekilde özetlemiştir: "Wozzeck'in karakterinde biraz da olsa benden birşeyler var, 
çünkü bu savaş yıllarını tıpkı nefret ettiğim birine bağlı olmak gibi, zincirlenmiş, esir, hasta, çaresiz hatta aşağılanmış bir şekilde geçiriyorum" (Glenn, 2002, s 235). Bu bağlamda Berg'in, savaş yıllarına ait mektup ve notları değerlendirildiğinde Wozzeck'i bitirmek için nasıl bir saplantı içinde olduğunu ortaya çıkmaktadır.

Berg'in savaş strasinda yaptığı 'Wozzeck' ve 'Orkestra için Üç Parça'sının kompozisyon şemaları ve notaları, askeri yönetmelikler ve terminoloji parçalarıla doludur. 1. perdenin 2. sahnesinde yer alan libretto taslağında Berg, Avusturya ordusunun borazan çağrılarına atıfta bulunan gösterimler kullanmıştır. Bu askeri sirenler daha sonra notasyona, atonal bir biçimde eklenmiştir ancak, bu benzetmeler sadece dönemin Avusturyal izleyicileri tarafindan fark edilebilmiştir. Berg benzer şekilde, 2. Perde, 5. Sahne'de yani "kışlada horlayan asker" sahnesinde bir anlatım gerçekleştirmiştir. Bu tuhaf, polifonik horlama korosu, Berg'in askerlik yillarina bir gönderme gibidir (Rose, 2013, s.375).

1919 yazına kadar 1. Perdeyi, 1921 Ağustos'unda 2. perdeyi ve sonraki iki ay boyunca son perdeyi (3. Perdeyi) yazmıştır. Sonraki altı ay süresince de orkestrasyonu sonuçlandırılmıştır. Berg, Nisan 1922'de Wozzeck'i tamamlamıştır. 1923'te piyano notasyonunun ortaya çıkışı, Berlin galası öncesinde tutkuyla yoğunlaşan tartışmalara yol açmıştır.

Operanın tipik bir gösteriminde birbuçuk saatten fazla sürmektedir.

\section{Performans geçmişi}

Erich Kleiber, Berg'in Wozzeck Operasını kendi girişimleriyle programa almış ve 14 Aralık 1925'te dünya prömiyerini Berlin Devlet Operası'nda (Berlin Staatsoper'de) gerçekleştirmiştir. Bu temsil Kleiber'in orkestra şefliğinde, Franz Ludwig Horth sahne yönetmenliğiyle ve Panos Aravantinos sahne tasarımıyla yapılmıştır. Oyuncular Leo Schutzendorf, Wozzeck; Sigrid Johanson, Marie; Waldemar Henke, Kaptan; Martin Abendroth, Doktor; Fritz Soot, Bando Şefi ve Gerhard Witting, Andres rollerinde görev almışlardır.

Bazı eleştirmenlerce opera, 'a succès de scandale (skandal bir başarı)' olarak değerlendirilmiştir. Basın, Kleiber'ın ve operanın aleyhine, prömiyer ve sonraki performanslarla ilgili karalama kampanyası 
yürütmeye başlamıştır. Eserin kostüm provasının Devlet Opera'sında karışıklığa ve kargaşaya neden olduğunu açıklayan The Berliner Lokalanzeiger, bu nedenden ötürü Wozzeck'in diğer temsillerinden vazgeçilmesi gerektiğini belirtmiştir. Deutsche Zeitung dergisinin eleştirmeni Paul Zschorlich, prömiyer sonrası Wozzeck'e yönelik saldırılarla ilgili bir yazı dizisi yayınlamıştır.

Berlin galasında izleyiciler arasında Prag Çek Ulusal Operası şefi olan Otokar Ostrcil bulunmaktadır. Ostrcil bu esere olan ilgisini çoktan dile getirmiştir. Eserin Prag'ta da temsilini gerçekleştirme konusundaki kararlılığı, Berlin temsili sonrasın iyice güçlenmiştir. "Güzel ve güçlü bir eser" olarak ifade ettiği Wozzeck hakkındaki düşüncelerini, galadan birkaç gün sonra, "Strauss'un Elektra'sından bu yana, en dikkat çeken yabancı opera" olarak niteleyerek bir yazı kaleme almıştır. Ostrcil göre eser, Mahler'den Schoenberg'e uzanan bir çizgide oldukça modern, otantik; yapı bakımından gerçekten yeni, bireysel ve özgündür. Çalışma bir sonraki sezon için programa alınmıştır. Ostrcil tarafindan $11 \mathrm{Kasım}$ 1926'da Prag galasına yapılmıştır. Prag'daki ilk iki gösteri halk tarafindan hem eleştirilmiş ve hem de beğeni toplamıştır. Bununla birlikte ü̧̈üncü temsilde opera yeniden hedef haline gelmiştir. Alman operasına itiraz eden Çek milliyetçileri tarafindan politik bir protesto eylemi yapılmıştır. Prag'taki üçüncü gösteri, final perdesinden önce durdurulmuş ve tiyatro boşaltılmıştır. Polis tarafindan gelecekteki temsiller yasaklanmiştır (Jarman, 1989, s.69).

Rus devrimini takip eden on yıl içinde Leningrad, özellikle aktif bir çağdaş sanat merkezi olmuştur. Wozzeck de bu sanatsal atmosfer içinde 1927-28 sezonunun programına alınmıştır. Nazilerin daha sonra 'kültürel Bolşevizm'in bir örneği' olarak ifade edilerek yasaklayacağ ilginç bir şekilde, Sovyet yetkililer tarafından da eleştirilmiş ve 'çökmekte olan burjuva sanatının bir örneği' olarak nitelendirilmiştir.

Prag'daki olaylı temsil sürecinin haberleri çok geçmeden Viyana'ya yayılmıştır. Skandal temel olarak Berg'in operasıyla ilgisi olmasa da, Wozzeck'in, Leningrad'taki başarısını etkilemiştir. Bu durumu sadece Almanya'da yapılacak başarılı bir temsil geri döndürebilmektedir. Bu 
nedenle Berg, Mart 1929'da, Oldenburg'ta, Johannes Schuler'in yönetiminde Wozzeck'in dördüncü temsilinin başarılı olması konusunda özellikle endişe taşımaktadır. Notasyonu Oldenburg'taki daha az sayıdaki bir orkestraya uyacak şekilde uyarlanmıştır. Performanstan önce prodüksiyon ekibine, opera hakkında tavsiye ve önerilerde bulunulmuştur. Sonuç olarak, Wozzeck'in Oldenburg'da, 5 Mart 1929'da yapılan prömiyeri başarılı bir şekilde gerçekleşmiştir.

Oldenburg temsili sonucunda pek çok küçük şirket çalışmaya ilgi duymaya başlamıştır. 12 ay boyunca, Aralı 1929 ile Aralık 1930 arasında ve yedi operada Wozzeck temsilleri yapılmıştır (Essen Aralık, 1929; Aachen -Şubat, 1930; Düsseldorf - Nisan, 1930; Konigsberg - Mayıs, 1930; Lubeck-Mayıs, 1930; Köln - Ekim, 1930 ve Gera - Aralık, 1930). Opera'nın devam eden başarısını sağlamak için Berg, bu performansların çoğuna katılmış ve Oldenburg için hazırladığı tanıtım konuşmalarını tekrarlamıştır. (Jarman, 1989, s.75).

Bu yedi yapımın hepsi eşit derecede başarılı değildir. Heinrich Jalowetz'in daha sonra 'duyduğum en iyi sahne gösterimi' olarak tanımladığı Aachen temsili, Berg'in model olarak kabul ettiği, bir başarıdır. Bu yapım turneye çıkmış ve 1930-31 sezonu boyunca Liege, Amsterdam ve Rotterdam'da temsil edilmiştir. Bu turne aynı zamanda operanın tanınmasında da önemli rol oynamıştır.

30 Mart 1930'da Wozzeck, nihayet Viyana Devlet Operası'nda temsil edilmiştir. Viyana'daki prova döneminde, Berlin'de olduğu gibi, operanın zorluklarıyla ilgili çeşitli dedikodular yayılmaya başlamıştır. Bu dedikodulara göre, Viyana Filarmoni eseri bölümler halinde prova etmek zorunda kalmıştır, ki bu daha önce asla yaşanmamış birşeydir. Aynı zamanda opera yine siyasi tartışmaların odağı olmuştur. 29 Mart 1930'da, Viyana galasından önceki gün, Avusturya Ulusal Sosyalist Partisinin resmi gazetesi olan Deutscheöster- reichische Tageszeitung şunları yazmıştır:

Şimdiye kadar yazılan en provokatif agit-prop çalışmalardan biri Alban Berg'in Wozzeck operasıdır. Georg Büchner'in oyunundan sonra pazar günü Viyana Devlet Operasi'nda ilk temsili yapilacaktır. Opera, Berlin ve Prag'da başarısız olmuştur. Schoenberg ve çevresinin tüm eserlerinin yayıncısı olan Universal Edition'la Vi- 
yana'daki yayınciların sözleşmeleri gereği bu opera, Berlin repertuarında zorunlu olarak yer almaktadır. Wozzeck sadece Leningrad'da kabul görmüş̧ür. Sosyal Demokratlar, Universal Edition ve Schoenberg'in çeoresiyle birlikte, bu çarpık çalışmanın propagandasını yapmak için pazar günü mümkün olan her şeyi yapacaklardır. Viyana halkının sağduyusu ve Avusturya Devleti yönetimi bu Avusturya-Marksist faaliyete hak ettiği cevabı verecektir. (Jarman, 1989, s.77).

$\mathrm{Bu}$ karalama kampanyalarına rağmen Viyana Prömiyeri oldukça başarılı geçmiştir. Anton Webern'de Wozzeck'i ilk kez Viyana'da izlemiştir. Webern, Schoenberg'e yazdığı bir mektupta "Viyana galasının başarısı gerçekten çok büyük... Opera beni derinlemesine etkiledi" ifadelerini kullanmıştır.

1931 yılında, Almanya'da altı farklı opera binalarında (Braunschweig, Darmstadt, Frankfurt, Wuppertal, Freiburg ve Leipzig'de) ve bir de Zürih Devlet Tiyatrosu'nda sekiz Wozzeck temsili yapılmıştır. Ancak 1931 temsillerin en önemlisi, Wozzeck'in Amerikan galasıdır. Bu gala 19 Mart'ta, Leopold Stokowski'nin orkestra yönetiminde Philadelphia'da yapılmıştır.

Wozzeck, Şubat 1932, Belçika, Brüksel'deki Theatre de la Monnaie'de temsil edilmiştir. Revue Musicale'ye göre solistler 1931 Mayıs'ından beri operayı incelemektedirler ve orkestra provaları da yoğun bir şekilde devam etmektedir. Bu yoğun hazırlığa rağmen, prömiyer için Brüksel'e seyahat eden Berg, işin başarı şansı konusunda endişelenmektedir. Bunun sebebi Brüksel'deki sanat çevreleri Berg'e göre çok muhafazakarlardır. Sonuç olarak, Berg'in endişelerine rağmen, Belçika prömiyeri de, başarılı olmuştur.

Bununla birlikte, Wozzeck'in temsil kariyerinin başlarında yaşadığ 1 siyasi sıkıntılar, geleceğini her zamankinden daha ciddi bir etkilemeye başlamıştır. Nazilerin artan gücü, tiyatro yöneticilerinin opera sahneleme isteklerini de etkilemeye başlamıştır. 1932'de Berlin Devlet Opera'sındaki iki Wozzeck temsili dışında sadece Coburg ve Mainz gibi bir-iki opera evinde temsil yapılabilmiştir. Kişisel olarak bir cesaret göstergesi sergileyen Erich Kleiber, 30 Kasım 1932'de Berlin'de Wozzeck'in sahnelenmesini sağlamıştır. Bu temsille birlikte on altı yıl boyunca Alman sahnelerinde operanın başka temsili yapılamamıştır. Operanın Aralık 1932'de, 
Brno'daki gösterimi ise Nazilerin Ocak 1933'te iktidara gelmesinden önceki son temsildir.

Naziler, 1933'ten sonra Wozzeck'i “çökmekte olan sanatın çöplüğ̈̈̈" olarak aşağılayana kadar, operanın Almanya ve Avusturya'da birçok temsili yapılmıştır. Başlangıçta, Wozzeck ana akım opera geleneğinde kendisi için sağlam bir yer edinmiştir ve Avrupa'nın büyük operalarının repertuarında yer almıştır. Berg de, bir süre eserinin telif hakları sayesinde rahat bir hayat yaşamıştır. 1920'li ve 30'lu yılları operasının temsillerine katılmak ve hakkında konuşmalar yapmakla geçirmiştir.

Wozzeck'in 14 Mart 1934'te, Londra, Queen Hall'da bir konser versiyonunu yapılmıştır. Bu konseri Adrian Boult'un yönetmiştir. Konser BBC'de canlı olarak, Avusturya'da da kayıttan yayınlanmıştır. Konserin Queen Hall'daki başarısından sonra, Covent Garden'da yapılabilecek bir opera temsiline fırsat tanınacağ ${ }_{1}$ Berg'e bildirilmiştir. 1935 Ocak ayına kadar bu temsil için planlar devam etmiştir. Yapımcı Otto Erhardt, besteciyle yapılacak çalışmaları tartışmak için Viyana'da gelmiştir. Ancak 1935 Londra yapılan BBC performansı ile on dört yıl sonra (savaş sonrası) yapılan ilk temsil arasında, 1942'de Roma'daki Teatro Reale dell'Opera' da sadece tek bir Wozzeck temsili yapılabilmiştir.

Savaş sonrası ilk Wozzeck temsili Haziran 1948'de Düsseldorlf'ta yapılmış olsa da, onu, takip eden süreçte (Nisan 1949'da Londra'da, Aralık 1950'de Paris'te ve Nisan 1951'de New York'ta) 1934'de, Londra'da yapılan konser versiyonuna benzer şekilde gösterimler izlemiştir. Operanın tekrardan sahne eseri olarak repertuarlarda yerini alabilmesi iki temsille gerçekleşmiştir. Bunlar, Aralık 1950'de Napoli'deki Teatro San Carlo'da ve 16 Ağustos 1951'de Salzburger Fest-spelhaus'ta yapılan gösterimlerdir. Bu temsiller Wozzeck'le yakından ilgilenen Karl Bohm tarafından yönetilmiştir. Wozzeck'in İngiltere galası nihayet Ocak 1952'de, Royal Opera House, Covent Garden'da gerçekleştirilmiştir.

Covent Garden, 1952 yılında opera temsil edildiğinde, İngiliz basını da gelişmeleri yakından takip etmiştir. Opera'nın prömiyerden önce, özel bir önizleme çalışması, Erwin Stein'ın operası hakkında bir tanıtım çalışması, Hugo Garten tarafından Büchner'e hakkında bir makale çalışması yapılmış ve Berg'in “Operalarımdaki müzik formları - Wozzeck" isimli kitabı İngilizce' ye çevrilmiştir. 
İngiliz eleştirmenlerin temel yaklaşımları, operanın müzikal yapısı değildir ancak, Sprechgesang'ın (şarkı ile konuşma arası bir söyleyiş biçimi) İngilizce'de uygulanabilirliği eleştirilerin temel konusudur.

Avrupa'daki opera kuruluşları savaşın etkilerinden kurtulmuş ve Wozzeck'e tekrar kapılarını açmışlardır. 1952-55 yılları arasında Milano ve Viyana'da birçok temsil gerçekleştirilmiştir.

1955 yılında Wozzeck, 14 Aralık'taki prömiyerinden otuz yıl sonra, Berlin Devlet Operasında tekrar temsil edilmiştir. Şefi 1929'da Oldenburg'taki temsili yapan Johannes Schuler'dır. Bu temsilin asıl önemi müzikal olmaktan çok politiktir. Berlin Devlet Operası, Kleiber'in yönetiminde Wozzeck'in ilk performansını 1925 'te gerçekleştirmiştir. Oysa 1955 yılında bu opera kentin Rus kontrolünde olan kısmının bir parçasıdır. Wozzeck'in performansları Sovyetler Birliği'nde yasaklandığından, Doğu Berlin Staatsoper'den sorumlu makamlar hem eserin tekrar temsil edilmesi kararını savunmakta, hem de kendilerini hala bu müzikten uzak tutmaya çalışmaktadırlar.

Sonuç olarak Alban Berg'in Wozzeck'i savaş yıllarından bile sağ kurtulmuş büyük bir sahne başarısını ifade etmektedir. Günümüzde hala operaların repertuarlarına alınmak istenen, modern bir eserdir. Her ne kadar Wozzeck, operaların repertuarında kalıcı bir yer edinse de, çalışılması zor bir operadır. Bu bakımdan Berg operanın çalışılma yöntemi konusunda belirli yönlendirmeler yapmıştır. Opera'nın vokal ve orkestra notasyonunun önüne basılan bu talimatlarda Berg şu şekilde açıklamalarda bulunur:

1. Ritme çok hassas bir şekilde sağdık kalınacak (nota değerlerine) ve normal şarkı söylemekten daha fazla özgürlüğe izin verilmeyecektir.

2. Şarkı söyleme ve konuşma sesleri arasındaki farkı anlamak: Şarkı söylerken sanatçı nota üzerinde değiş̧iklik yapmadan kalır. Konuşmada ise notaya vurur ancak, hemen yükselip veya alçalarak perdesini terk eder ve her zaman ilişki içinde olduğu diğer notalarm perdelerine doğru hareket eder.

Sanatçı, şarkı söyler gibi konuşmamaya büyük özen göstermelidir. Bu, bestecinin amaçladığı birşey değildir ancak, gerçekçi, doğal bir konuşma tarzı da istemez. Aksine, sıradan konuşma ile 
müzikte kullanılabilecek konuşma arasındaki fark açık olmalıdır. Öte yandan, şarkı söyler gibi de olmamalıdır. (Jarman, 1989, s.88).

Berg, 1930 tarihli “Wozzeck" in hazırlanması ve sahnelenmesi” adlı bu konuşmasını genişletmiştir.

Hiçbir koşulda şarkı söylemek yok! Yine de, perdeler tam olarak notlarda belirtildiği gibi belirtilmeli ve tutulmalıdır. Emin olmak için böyle bir konuşmanın baştan sona göğ̈̈s tonuyla sinırl olmasina gerek yoktur. Normal konuşma sesi genellikle çok düşük ve sinırl bir aralıkta olduğu için, kafa tonları da uygulanabilir. Bu nedenle konuşma sesleri, farkl ifadeleri dile getirmek için, uygun ses tonlarında ve şarkıciya zorluk veya zarar vermeyecek şekilde kullanilmalıdır.

Sadece, bu yönlere rağmen, doğal olmayan ve şekillendirilmiş bir ses tımısının (yüksek veya düşük aralıklarda) kaçınılmaz olduğu durumlarda, konuşulan melodiyi daha dar bir sinırda kullanmasına izin verilir. Bununla birlikte, bireysel perdelerin bir diğeriyle ilişkisi korunmalıdir. (Jarman, 1989, s.88).

Berg'in bu ayrıntılı talimatlarına rağmen, Sprechgesang'ın uygulanabilirliği hala bir tartışma konusu olmaya devam etmektedir.

\section{Müziksel yapısı}

“Wozzeck, müzikal içeriğindeki modernist unsurlara rağmen, eski formların ustaca kullanıldığı bir eserdir. Aynı zamanda dramatik olayların müzikal anlamdaki ifadeleri dikkatli bir tutarlılıkla gerçekleşmiştir." (Reich, 1932, s.4). Her sahne klasik operalarda olduğu gibi belirli biçimlerle işlenmiştir (Üç tema üzerine fantazi ve füg, yirmi varyasyondan kurulu bir süit gibi).

Berg'e göre operada seyirci, Wozzeck'in psikolojik kaosunu anlayabilmelidir. Bu ancak müzikal bir ifadeyle gerçekleştirilebilir. Böyle bir müziğin oluşturulmasında Berg, birçok yaratıcı girişimlerde bulunmuştur. Örneğin orkestrayı birçok yerde bir efekt unsuru olarak kullanmıştır.

Berg, Woyzeck oyununu kendi kompozisyonel gelişiminde bakımından, doğru zamanda izlemiştir. Berg'in kompozisyon öğretmeni Arnold 
Schoenberg, 1905'te, 19. yüzyıl klasik müziğinin temelini oluşturan tonal sistemi bir kenara bırakarak yeni ve deneysel bir müzik düşüncesi için harekete geçmiştir. Bu müziksel çizgiyi takip eden Berg, Üç Orkestra Orkestrası'nda (1914) birlikte daha büyük ölçekte atonal eserler bestelenmesini sağlayan yapısal araçları bir araya getiren ilk besteci olmuştur. Bu eserde edindiği bestecilik deneyimleri Wozzeck'in yolunu açmıştır.

Wozzeck'de Berg, Büchner'in metninin dramatik yapısına ve sosyal anlamdaki eleştirel tutumuna, oyunun farklı karakterleri ve bölümleri arasında bir birliktelik yaratarak, sağlam bir müzikal yapıyla karşılık vermiştir. Berg, Büchner'in oyununun 25 sahnesinden ${ }^{3} 15$ 'ini seçmiş ve her birini beş sahneden oluşan üç perdeye ayırmıştır. Daha sonra her bir perde şu şekilde oluşturulmuştur: Beş Müziksel Stil (1. perde), Beş Formlu Senfoni (2. perde) ve Altı İnvansiyon Kümesi (3. perde). Bu genel tasarım içerisinde, her bir sahne için de farklı müzikal formlar oluşturulmuştur.

Aşağıdaki tablo, Fritz Mahler'in hazırladığı dramatik yapıyı ve formları özetlemektedir. ${ }^{4}$

\begin{tabular}{|l|l|l|}
\hline Drama & & Müzik \\
\hline Giriş (Serim) & 1. Perde & Beş Müziksel Stil \\
\hline Wozzeck ve Kaptan & 1. Sahne & Süit \\
\hline Wozzeck ve Andres & 2. Sahne & Rapsodi \\
\hline Wozzeck ve Marie & 3. Sahne & Askeri marş ve Lullaby (Ninni) \\
\hline Wozzeck ve Doktor & 4. Sahne & Pasaj \\
\hline Marie ve Bando Şefi & 5. Sahne & Andante affettuoso (Rondo gibi) \\
\hline Dramatik Gelişim & 2. Perde & Beş Formlu Senfoni \\
\hline Marie ve oğlu, sonra Wozzeck & 1. Sahne & Sonat \\
\hline Kaptan ve Doktor, sonra Wozzeck & 2. Sahne & Fantazi ve Füg \\
\hline Marie ve Wozzeck & 3. Sahne & Largo \\
\hline Bir tavernanın bahçesi & 4. Sahne & Scherzo \\
\hline Kışlada bir bahçe odası & 5. Sahne & Rondo con introduzione \\
\hline Felaket (Son Bölüm) & 3. Perde & Altı İnvansiyon \\
\hline Marie ve oğlu & 1. Sahne & Tek tema üzerinde invasiyon \\
\hline
\end{tabular}

\footnotetext{
${ }^{3}$ Büchner'in Woyzeck'i bazı kaynaklarda 25, bazısında ise 26 sahne olarak belirtilmektedir. Bunun nedeninin oyunun orijinal metninin kaç sahne olduğunun netleşememesinden kaynakladığı düşünülmektedir.

${ }^{4}$ W. Reich, 1932, s.7.
} 


\begin{tabular}{|l|l|l|}
\hline Marie ve Wozzeck & 2. Sahne & Tek nota üzerinde invansiyon (Bघ) \\
\hline Taverna (Bar) & 3. Sahne & Tek ritm üzerinde invansiyon \\
\hline Wozzeck'in ölümü & 4. Sahne & Tek hexachord üzerinde invansiyon \\
\hline & İnterlüt & Tek ton üzerinde invansiyon (D minor) \\
\hline Çocukların oyunu & 5. Sahne & $\begin{array}{l}\text { Düzenli tek bir quaver formu üzerinde invansiyon } \\
\text { (Perpetuum Mobile) }\end{array}$ \\
\hline
\end{tabular}

Berg, seçtiği klasik formları biraraya getirmiş ve bu formsal yapılarla her bir sahnesinin dramatik ve psikolojik özünü aydınlatmak istemiştir.

Aşırı duygusal güç ile gizli fakat sıkı kontrol arasındaki yaratıcı gerilim, sadece operanın biçimsel tasarımında değil, klasik operanınkilerin ötesine geçen vokal kullanım tekniklerinde de görülmektedir. Sıradan konuşmadan, notalı sözcüklere; tam şarkıdan ve süslemelere kadar her ses kesin bir şekilde notasyonda ifade edilmiş, ses ve cümleler dengelenmiştir.

Berg kariyeri boyunca, Mahler'in yaratıcı kişiliğine sıcak bir hayranlık beslemiştir. Bu nedenle de Wozzeck'i Mahler'in dul eşi Alma Mahler Werfel'e ithaf etmiştir. Berg'in birçok eseri, Mahler'in amaçladığı müzikteki mantıksal gelişimin yerine getirilmesi olarak görülebilir. Ancak bununla birlikte Berg, orijinal fikirleri kendi tarzında geliştirerek, özgün anlatımını oluşturmuştur.

1914'te Berg opera Wozzeck'i oluşturmaya karar verdiğinde, müzikte dünyasindaki durum biraz tuhaftır. Arnold Schoenberg liderliğindeki Viyana okulu, "atonalite" olarak bilinen hareketin ilk aşamalarının ötesine daha yeni gelmiştir. Bu stildeki kompozisyonlar henüz şarkılar, piyano ve orkestra parçalarn gibi kü̧̈ük formlarla sinırlıdır. Ortalama uzunlukta ve büyük yapıda (senfoni, oratoryo ve opera gibi) atonal eser daha yazllmamiştır. Tonaliteden uzaklaşarak bu okul, sadece küçük formları değil, büyük biçimleri; daha önceden denenmiş ve başarılı olduğu anlaşılmış birçok müziksel anlayışı reddetmişlerdir. Berg bir opera yazmaya karar verdiğinde, uyum konusunda yeni birçok problemle karşı karşıya kalmıştır. Kanıtlanmış formlar ve buna dayanan biçimsel tekniklerin sağladığ̆ imkanlar olmadan, aynı bütünlüğ̈̈ ve ikna edici müzikal tutarlılı̆̆l sağlaması büyük bir sorunu ifade etmektedir. (Reich, 1932, s.5). 
Tek başına metinin mimarisi, Berg'e bu sorunlarına çözüm üretememiş, biçim birliğini garanti edememiştir. Büchner'ın Woyzeck'i pek çok gevşek ve parçalı bir yapıda olduğu için sahneler elden geçmek zorunda kalmıştır. On beş sahneye dönüştürülen opera, giriş dramatik gelişme ve felaket diye ayıran üç perdeli düzenleme yapıldığında, dramatik yapıyla tutarlı müzikal bir düşünce henüz hazır değildir. Bu konuda Berg, sahnelerin dramatik hareketliliğine uygun müzikal stil ve formları bir araya getirme kararı almış ve soruna çözüm üretmek istemiştir.

Berg'in müzikal çeşitlilik arzusu, Wagner'den beri müziksel dramanın ortak özelliği olan "durchkomponieren" (bütüncül ve tutarlı bir beste oluşturma) düşüncesinden kaçınmasını sağlamıştır. Wozzeck'te her bir farklı sahne farklı bir müziksel stilde tasarlanmıştır. Buna rağmen yine de bu sahnelerin her birinin tamamlanması, müzikal bir bütünlüğü de gerekli kılmıştır. Tek tek müzikal bölümlerin sanatsal olarak kaynaşması zorunluluğunu, onlara tam anlamıyla doğru formu vermeyi gerektirmektedir. Aynı şey sahne üzerindeki dramatik hareketliliğe de uygulanmıştır. $\mathrm{Bu}$ amaç için seçilen müziksel formların doğallığı sahne bölümlerinin birbirine bağlanmasını da kolaylaştırmıştır.

Berg, operadaki tutarlılığ sağlamak için söz edilen müziksel form çeşitliliğinin yanında farklı müzikal teknikler de kullanmıştır. Bu tekniklerden en önemlisi 'Leitmotif'dir. Lietmotifin kullanımı Berg'in müziğinde diğer çoğu besteciden farklı bir yapıdadır. Her bir motifi, bir karakter veya nesneye doğrudan iliştirilmek yerine çok daha incelikli bir şekilde kullanmıştır. Bununla birlikte Kaptan, Doktor ve Bando Şefi için kullanılan motifler de oldukça belirgindir. Yine biri sahneye girip çıkarken sıklıkla duyulan veya Wozzeck'in yaşadığı baskılar karşısında acısını ve çaresizliğini dile getirdiği sırada kullanılan motifler açıkça anlaşılabilmektedir. Marie, Bando Şefi'nin armağanı bir çift küpeyi kabul ettiğinde, onun duygu durumunu ifade eden motifler eşlik eder. Kısaca özetlenmek istendiğinde, fiziksel bir nesneyle açıkça bağlantılı olmayan motifler, operanın birçok yerinde duygu durumlarıla ilişkilendirilerek kullanılmıştır.

Berg, bu opera için 'Aria' veya 'trio' gibi klasik opera formlarının kullanılmasına da karşı durmuştur. Bunun yerine, her sahnede soyut enstrümantal müzikle daha normal olarak ilişkilendirilebilecek stil ve 
formların kullanılmasıyla operanın iç tutarlılı̆̆ını ortaya koymuştur. Örneğin, 2. Perdenin 2. Sahnesi (Doktor ve Kaptan'ın Marie'nin sadakati ile ilgili Wozzeck'le alay ettikleri süre boyunca), bir prelüt ve üçlü fügden oluşmaktadır. Benzer şekilde Wozzeck ve Doktor'a odaklanan 1. Perdenin 4. sahnesi de bir pasaj'dir.

Wozzeck genellikle 20. yüzyıl avant-garde tarzında üretilen ilk opera olarak kabul edilmesinin yanında, ayn zamanda atonalitenin ve Sprechgesang'ın kullanmanın en önemli örneklerinden biridir. Berg, duygularını ve hatta sahnedeki karakterlerin düşünce süreçlerini ifade etmek için özgür atonaliteyi kullanmıştır. Delilik, çlgınlık, cinnet ve yabancılaşma duygusunun ifadesi atonal müzikle güçlendirilmiştir. Wozzeck atonal bir müzik örneği olmasına rağmen, müziksel parçalar armonik ilerleyiş doğrultusunda perde kontrolünü sağlayabilmek için farklı yöntemlerle yazılmıştır. Örneğin B - F tritonu, Wozzeck ve Marie'yi, sürekli birbirleriyle mücadelede temsil etmektedir. Benzer şeklide, Bb ve Db (küçük üçlü) birleşimi de Marie ve oğlu arasındaki bağın anlatımıdır. Bu sayede opera, hikâyedeki önemli anları belirtmek için sürekli olarak belirli perdelere geri dönmüştür. Bu elbette sabit merkezli bir tonalite düşüncesiyle aynı şey değildir ancak, zamanla bu perdelerin tekrarlanması devamlılığın ve yapının oluşmasına katkı sağlamıştır.

3. Perdenin çeşitli sahnelerinde bu yapıların da ötesine geçilmiş ve yeni stratejiler benimsenmiştir. Her sahne bir varyasyon kümesi olarak tasarlanmıştır. Ancak 'varyasyon' teriminin normal olarak bir melodinin çeşitlemesi olduğu düşüncesinin aksine Berg, 'varyasyon' için farklı müzikal unsurlar tanımlamıştır. Bu bağlamda örneğin 2. Sahne' de sürekli olarak duyulan tek nota (Bদ)); 2. Sahne'nin sonunda güçlü orkestra kreşendosunda duyulan tek nota üzerindeki ritmik desen ve bu desen etrafında her büyük tematik yapı, bir varyasyondur. Yine bunlara ek olarak, 4 . Sahne'nin müzikal yapısı, tüm sahne için kullanılan bir akorun varyasyonudur.

Berg, Wozzeck'te oldukça büyük bir orkestra için nota yazmıştır. Bu büyük orkestraya ek olarak sahne üzerinde de üç ansambılı bir araya getirilmiştir (1. Perde 3. Sahne'de bir bandoyu; 2. Perde, 3. Sahne'de bir oda orkestrasını; 2. Perde, 4. Sahne'de bir meyhane grubunu sahne 
üzerinde kullanmıştır). Bu ansambıllara ek olarak 3. Perde, 3. Sahne'de de bir duvar piyanosunu sahne üzerinde kullanmıştır.

\section{Özet}

Konun geçtiği zaman ve yer: Birinci Dünya Savaşından önce Almanya'da askeri bir bölgedeki şehir.

\begin{tabular}{|l|l|}
\hline Roller & Ses Tipi \\
\hline Wozzeck & Bariton \\
\hline Marie, Wozzeck'in metresi & $\underline{\text { Soprano }}$ \\
\hline Marie'nin Oğlu & Treble (Tiz Sesli Çocuk) \\
\hline Yüzbaşı (Kaptan) & Buffo $\underline{\text { Tenor }}$ \\
\hline Doktor & Buffo Bass \\
\hline Bando Şefi & Helden Tenor \\
\hline Andres, Wozzeck'in arkadaşı & Lirik Tenor \\
\hline Margret, Marie'nin komşusu & Kontralto \\
\hline 1. Çırak & Koyu Bas \\
\hline 2. Çırak & Yüksek Bariton \\
\hline Deli Bir Adam & Yüksek Tenor \\
\hline Bir Asker & Bariton \\
\hline Askerler, çıraklar, kadınlar, çocuklar & \\
\hline
\end{tabular}

\section{Perde}

1. Sahne (Süit): Wozzeck alt rütbe bir askerdir (bir er'dir). Askeri bölge içinde bir yerde, Yüzbaşı'sını (Kaptan'ı) tıraş etmektedir. Kaptan, 'terbiyeli bir adamın' nitelikleri hakkında ders vermekte ve ahlaksız bir hayat sürdüğü için Wozzeck'le dalga geçmektedir. Wozzeck acımasız, "Jawohl, Herr Hauptmann" ("Evet efendim, tabi Kaptan...") Kaptan'in alay etmelerine tekrar tekrar cevap vermektedir. Bununla birlikte, söz birden Wozzeck'in evlilik dışı çocuğuna gelir. Kaptan Wozzeck'i 'Kilise'nin nimeti olmadan' bir çocuk sahibi olduğu için eleştirdiği zaman, Wozzeck buna karşı çıkarak ve fakirken erdemli olmanın zor olduğunu söyler ve Kaptan'a İncil'den bir alıntılya karşılık verir: "Lasset die Kleinen zu mir 
kommen! " (Küçük çocukların bana gelmelerine izin ver). Kaptan, Wozzeck'in din bilgisi karşısında şaşkına döner ve rahatsız olur. Wozzeck şayet varlıklı olsaydı, ahlaklı olmanın kolay olacağından söz ederek konuşmaya devam eder. Bu söz üzerine iyice sinirlenen Kaptan, Wozzeck'i anlayamadığından söz eder ve "iyi bir adam olarak çok fazla düşündüğünü" söyler ve "oldukça yorulduğunu" söyleyerek tartışmayı sonlandırır. Dışarı çıkmaya yöneldiğinde de Wozzeck'i son bir kez azarlar.

2. Sahne (Rapsodi ve Av Şarkısı): Wozzeck arkadaşı Andres boş bir araziye uzanmış vakit geçirmektedirler. Andres bir av şarkısı söylemektedir (Das ist die schöne jaegerei). Wozzeck ve Andres güneş batarken, ağaç dallarını kesmeye başlarlar. Birden Wozzeck korkunç hayaller, görüntüler görür. Üç gün içinde öleceğinden söz eder. Andres ise onu sakinleştirmeye çalışır fakat başarısız olur. Wozzeck ölümden söz ederken perde iner.

3. Sahne (Marş ve Lullaby (Ninni): Marie'nin odasının dışından bir askeri geçit töreni geçmektedir. Marie o fakir odasından dışarıdaki töreni izlemektedir. Yakışıklı Bando Şefi'yle uzaktan flörtleşir. Margret, askerlerle flört ettiği için Marie'yle alay etmektedir. Marie pencereyi kapatır ve oğluna bir ninni söylemeye başlar (Maedel, was faengst du jetzt an?). Daha sonra kapı çalınır ve Wozzeck gelir. Marie'ye, gördüğü korkunç hayallerden söz eder. Fakir olmaktan korkmaktadır. Tedirgin bir şekilde odadan çıııp gider. Marie Wozzeck'in iyiden iyiye delirdiğini düşünür ve söylenerek kapıyı ardından kapatır.

4. Sahne (Pasaj): Askeri bölge içindeki doktorun odası. Wozzeck doktora muayene olmaktadır. Doktor diyetine dikkat etmeyip sağlıksız yaşadığ1 için için Wozzeck'i azarlamaktadır. Doktor tıbbi bir deney için Wozzeck'i denek olarak kullanmakta, karşılığında para vermektedir. Wozzeck Marie ve oğlu için ek gelir kazanmak adına bu deneyi sürdürmektedir. Wozzeck dünyayı saran alevler gördügüunü Doktor'a da anlatır. Doktor, Wozzeck'in zihinsel sıkıntılarını duyduğunda çok memnun olur ve Wozzeck üzerindeki deneyinin başarılı olduğunu söyler. Muayene sürerken perde kapanir. 
5. Sahne (Rondo): Gece vaktidir. Marie, odasının dışında durmakta olan Bando Şefi'ne hayranlıkla bakmaktadır. İkisi de birbirilerini arzulamaktadırlar. Marie önce kendine kur yapan Bando Şefi'ni reddeder ancak kısa bir süre sonra onu kabul eder ve eve girerler.

\section{Perde}

1. Sahne (Sonat-Allegro): Yine Marie'nin odası görülmektedir. Bando Şefi'nin ona verdiği küpeleri hayranlıkla inceleyen Marie, bir taraftan da çocuğunu uyutmaktadır. Sonrasında kalkar ve aynanın yanına geçer. Saçını düzeltip küpesini takar. O sırada Wozzeck gelir. Marie bir an için korkar ve panikler. Wozzeck küpeleri nereden aldığını sorduğunda da, onları bulduğunu söyler. İkna olmamasına reğmen Wozzeck, Marie'ye, Doktor'un deney karşılığında ona verdiği parayı verir ve dışarı çıkar. Marie davranışlarından dolayı pişmanlık duymakta ve intiharı bile düşünmektedir.

2. Sahne (Fantazi ve Ü̧̈ Temalı Füg): Doktor, Kaptan tarafından sokakta koşuşturulmaktadır. Doktor yavaşlamalarını ister yoksa kalp rahatsızlığının ona sıkıntı vereceğinden söz eder. Doktor daha sonra, aynı rahatsızlıkların kendisinde de oluşabileceğinden söz ederek Kaptan'ı korkutur. Bu sırada oradan geçmek olan Wozzeck'i görürler. Wozzeck geldiğinde, her ikisi de Marie'nin onu Bando Şefi'yle aldattı̆̆ını ima ederler. Wozzeck ölümden söz ederek yanlarından uzaklaşır.

3. Sahne (Largo): Wozzeck, Marie'nin odasına gittiğinde, o kapının önündedir. Wozzeck suçlamalarını inkâr eden Marie ile yüzleşir. Çok sinirlenir, Marie'ye vurmaya kalkışır. Tam bu anda Marie, babasının bile ona vurmaya cesaret edemediğini söyler. Marie'nin “karnımdaki bir bıçak üzerimdeki senin ellerinden daha iyidir" sözleriyle birlikte iyice sinirlenen Wozzeck'in aklında intikam almak fikir oluşur.

4. Sahne (Scherzo): Bir taverna'nın bahçesi. Kalabalık arasında Wozzeck, Marie'nin Bando Şefi'yle dans ettiğini görmüştür. Andres birkaç sarhoşla birlikte av hakkında şarkı söylemektedir. Wozzeck yavaşça içeri girer ve bir köşeden Marie ile Bando Şefi'ni seyreder. Andres arkadaşı Wozzeck'e 
neden tek başına oturduğunu sorar. Wozzeck, bu sırada Marie ve Bando Şefi'ne saldırmayı düşünür ama vazgeçer. Sarhoş bir çırak ortalığa nutuk atmaktadır. Sonra bir deli Wozzeck'e yaklaşır ve şu sözleri söyler: 'Eğlence, eğlence, ama korkunç... kan kokusu alıyorum, kan kokusu' ("Lustig, lustig ... aber es riecht ... Ich riech, ich riech Blut!").

5. Sahne (Rondo): Askeri bölge içindeki bir koğuş. Bütün askerler uyumaktadır. Kıskançlıktan uyuyamayan Wozzeck, Andres'i de uyutmamaktadır. Andres'e rüyasında garip bir müzik dinlediğini ve elinde büyük bir bıçakla Marie'yi gördügünü söyler. Bu sırada Bando Şefi gelir. Sarhoştur ve Wozzeck'i onunla savaşmak için yatağından çıarır. Wozzeck, Marie yüzünden Bando Şefi'nden dayak yer ve yere yuvarlanır. Wozzeck gururu iyice kırılmış bir şekilde söylenirken, diğer askerler tekrardan uyumaya başlarlar. Perde iner.

\section{Perde}

1. Sahne (Tek tema üzerinde invansiyon): Gece odasındaki Marie, İncil okumaktadır. Wozzeck'i aldattığı için pişmanlık içindedir. O sırada huzursuzluk yapan oğluna bir hikâye anlatır. Sonra tekrar Tanrı'dan kendisi affetmesini ister ve bağışlanmak istediğini haykırır.

2. Sahne (Tek nota üzerine invansiyon (B)): Wozzeck ve Marie bir gölet tarafından ormanda yürümektedirler. Bir ara duraklarlar. O sırada Wozzeck eski günlerdeki gibi Marie'yi öpmek ister ancak Marie onu engeller ve oradan ayrılmak ister. Wozzeck onu engeller. Kan kırmızısı bir ay yükselirken, Marie iyice tedirgin olmuştur. Wozzeck, Marie'ye kendisi sahip olamazsa, kimsenin de olamayacağını söyler. Böyle bir durumda Marie'yi bıçaklamaya karar verir. Bıçağı bir anda çeker ve kadının boğazını keser. Marie'yi ölüme terk ederek oradan kaçar.

3. Sahne (Tek ritm üzerinde invansiyon): İnsanlar bir tavernada dans etmektedirler. Wozzeck içeri girer ve Margret'i gördükten sonra onunla dans eder ve kucağına çeker. Onu aşağılar bir şekilde, şarkı söylemeye zorlar. Margret şarkısını söyler, fakat bu sırada Wozzeck elindeki kanı fark eder. Sonrasında tavernadaki herkes ona bu kan lekelerinin nedeni 
sorar ve bağrışmalar başlar. Elini kestiğini söyleyen Wozzeck tedirgin ve panik bir şekilde tavernanın dışına çıkar.

4. Sahne (Tek hexachord üzerinde invansiyon): Wozzeck cinayet mahalline geri döner. Marie'nin cesedinin yanına gider. Kadını öldürdüğü bıçak yüzünden suçlanacağını düşünerek, suç aletini gölete fırlatmaya kalkışır. Cinayetten dolayı korku ve pişmanlık içindedir. Kan kırmızısı ay tekrar görünmektedir ve suyun rengi de kırmızıya dönüşmüştür. Bu kan kırmızısı gölette yıkanmak ister. Bir taraftan da bıçağı kıyıdan yeterince uzağa atmadığını düşünmektedir. Ayrıca kıyafetini ve ellerindeki kan lekesini de temizlemek istemektedir. Wozzeck, gölete girer ve boğulur. Kaptan ve Doktor, oradan geçerken, Wozzeck'in inlemelerini duyarlar ancak tepki vermezler. Sesler bir süre sonra kesilir. Kaptan ve Doktor yollarına devam ederler.

İnterlüt (Tek ton üzerinde invansiyon (D minör))

Sadece müzikle yapılanmış bu ara bölüm, operanın finaline hazırlık niteliğindedir.

\section{Sahne (Sekizinci derece ïzerinde invansiyon) (toccata gibi moto per-} petuo): Birgün sonranın sabahında, çocuklar gün ışığında, sokakta oynamaktadırlar. Marie'nin cesedinin bulunduğu ile ilgili haberler yayılır. Haberi Marie'nin oğluna söylerler. Çocuk bir an için duraksar sonra tekrar oyuncak atıyla oynamaya devam eder. Marie'nin küçük oğlu dışında, kalabalık olaylardan habersizce olay yerine koşar. Perde iner, opera biter.

\section{Sonuç}

Alban Berg'in Wozzeck operası hakkındaki bu incelemede, operanın tarihsel süreci ele alınmış ve şu sonuçlara ulaşılmıştır:

Wozzeck, sadece 20 yy.'in opera müziği için değil, aynı zamanda genel müziksel anlayışı için de önem taşıyan bir eseri ifade etmektedir. Müziksel gücü, librettosunu destekleyen anlatım dilinden kaynaklanmaktadır. Yazıldığı tarihlerde (1914 ile 1922 yılları arasında) hala kurumsal bir atonal müzik geleneği oluşmamıştır. Berg'in bu operasındaki arayışları ve yeni bir müzik düşüncesi için çözüm üretme çabaları, 20. yy'ın atonal müziğine büyük katkı sağlamıştır. Wozzeck her ne kadar tipik bir atonal 
müzik örneği değilse de, uzunluğu ve bütüncül yapısı gereği, döneminin müzik anlayışı için bir model niteliğindedir.

Wozzeck'in sanatsal değeri sadece müziksel yapısının niteliğinden de kaynaklanmamaktadır. Opera bu müziksel dilin oluşmasını sağlayan güçlü bir librettoya sahiptir. George Büchner'in "Woyzeck" isimli dramasından uyarlanan bu libretto, operanın ilk sahnelendiği yıllarda başına gelen birçok olayında temel sebebidir. Bu bağlamda operanın hem müziğinin hem de metninin döneminin öncü bir sanat anlayışına hizmet ettiğini söylemek mümkündür.

Wozzeck operası 1925 'de prömiyer yapmıştır. Bu tarihten sonra opera, özellikle Nazi'lerin Almanya'da açıkça bir güce dönüşmeleriyle birlikte, birçok yasağa maruz kalmıştır. Bütün bu yasaklı sürece rağmen, Wozzeck'e duyulan ilgi azalmamıştır. Günümüz de hala merak uyandıran bir opera olarak, başta Avrupa'dakiler olmak üzere, birçok opera kurumunun repertuarında yer almaktadır. Bestelenmesinin üzerinden yüzyıla yakın bir süre geçmesine rağmen Berg'in eserine karşı olan bu ilginin nedeni, operanın kendine özgü yapısıdır. Operadaki müziksel ve dramatik yapıyla birlikte, insanın en karanlık taraflarını bile dile getiren bir anlatım oluşmaktadır. Bu da Wozzeck'in hala tartışmalara konu olan ve ilgi uyandıran özgünlügünü belirtmektedir. 


\section{EXTENDED ABSTRACT}

\section{A Historical Review About Alban Berg's Wozzeck \\ R. Görkem Aytimur \\ Tokat Gaziosmanpaşa University}

In this study, a historical examination was made about Wozzeck, the first opera of Alban Berg. The originality of structure of the opera is discussed in the historical context. In terms of the conceptual integrity of the work, the musical language and the subject of the work are also mentioned, but the focus is mainly on the conditions of the opera in the historical process. Thus, the place and importance of Wozzeck in the operas of the 20th century were expressed.

Wozzeck opera, which is one of the most important examples of avantgarde and expressionist music language in the early years of the 20th century, is also a building block for the development of atonal music. Berg's ingenious solutions in terms of tonal-atonal music transformation underlined the importance of the opera once again in the process that preceded the twelve-tone system, which has not yet been institutionalized. Considering the historical quality, the study of opera in this context expresses the importance of the study.

In this study, Wozzeck's adaptation from theatrical text to libretto, its composition and representation processes are examined. The avand-garde language of the opera's musical and dramatic understanding has been the focus of many discussions since its composition.

Wozzeck, the first opera of Austrian composer Alban Berg, was written between 1914-1922. The opera was first performed in 1925. The text of the opera was taken from Woyzeck, a drama written by German playwright George Büchner.

Berg's Wozzeck is one of the most important operas composed in the first half of the 20th century. It is especially important in terms of its place in the opera repertoire after Wagner. The repertoire choices of many opera houses in the European opera industry are in the direction of choosing classical works that are sure to attract audiences of the 18th and 19th century operas. The 20th century operas, which enter into the repertoire of these opera houses, are also mostly chosen from examples using a traditional music language. In this sense, the operas of Alban Berg are exceptions. Both the operas of Alban Berg 
(Wozzeck and Lulu), despite having a radical musical language, were both included in these repertoires and preserved their artistic power from the day it was first staged.

In the musical design of Wozzeck, Berg presented masterly and original solutions to the demands and wishes of the changing art world of the 20th century. On the other hand, Berg's perspective did not become a model for later composers. The main reason for this is that Berg's way of establishing the relationship between musical forms and dramatic movements in Wozzeck is unique to him.

Wozzeck contains experimental studies in mental and emotional terms, which until then were not considered appropriate for any form of staging. In this respect, it represents a radical position within the theater repertoire. The neurotic transitions of the characters to the madness and musical and dramatic solutions to use these situations on the stage can seen also in other operas of the late 19th century. But like no other opera Wozzeck, its psychological depth has such a complex "anti-hero" character. In this sense, the perception of the effect of Wozzeck character on the mental imbalance by the audience is as strong as it has never been in an opera before.

The powerful dramatic effect of Berg's opera is due to the fact that the audience is forced to experience what Wozzeck experiences in his critical moments and to feel his terrible hallucinations about the world. But what we see in Wozzeck is not a reflection of a simple mind. It is also not only a picture of a deceived person and of an emotionless society. It is a neurotic opposition to both social order and the nature of the world, as the musical structure makes it clear.

Berg began to work on the opera in 1914, but with the beginning of World War I, he went to the army as a soldier. For this reason, until his resignation from military service in 1917, he had to pause his work. In 1918, he began to focus again on his opera. Berg's war experience has a significant impact on Wozzeck's dramatic and composition aspects.

He wrote Act 1 until summer 1919, Act 2 in August 1921 and last act for the next two months (Act 3). The orchestration was concluded during the next six months. Berg completed Wozzeck in April 1922. The emergence of piano notation in 1923 led to a passion-intensive debate before the Berlin premiere. 
Erich Kleiber made Berg's Wozzeck Opera on his own initiative and made its world premiere on December 14, 1925 at the Berlin State Opera (Staatsoper). This representation was made by Kleiber conductor, Franz Ludwig Horth stage director and Panos Aravantinos stage design.

After Wozzeck's world premiere in 1925, it was exposed to many prohibitions, especially when the Nazis turned into clear power in Germany. Despite all this banned process, interest in Wozzeck has not diminished. Today, it is still an intriguing opera and is included in the repertoire of many opera institutions, especially in Europe. Although it was almost a century since its composition, the reason for this interest in Berg's work is the unique structure of the opera. Along with the musical and dramatic structure in the opera, a narrative is created that expresses even the darkest parts of human beings. This demonstrates Wozzeck's originality, which is still controversial and of interest.

\section{Kaynakça / References}

Glenn, W. (2002). Proof through the night: Music and the great war. Kaliforniya: University of California Press.

Jarman, D. (1989). Alban Berg, Wozzeck. İngiltere: Cambridge University Press. John, N. (Ed.). (1990). Wozzeck, Opera Guide Series. Southampton: The Southampton Book Co.

Lucentini, V. (2013). Performance as source. A new document on the genesis of Berg's Wozzeck Schweizer Jahrbuch für Musikwissenschaft Neue Folge 33. 20/03/2019 tarihinde https://www.academia.edu/19395935/Performance_as_source._A_new_document_on_the_genesis_of_Bergs_Wozzeck._In_Schweizer_Jahrbuch_für_Musikwissenschaft_Peter_Lang_33_2015 adresinden erişilmiştir.

Reich, W. (1932). A Guide to Alban Berg's Opera Wozzeck. 17/03/2019 tarihinde http://ada.evergreen.edu/ arunc/texts/wozzeck/wozzeck.-pdf adresinden erişilmiştir.

Rose, M. (2013). The Birth of an Opera: Fifteen Masterpieces from Poppea to Wozzeck. New York: W. W. Norton \& Company.

Sandu-Dediu, V. Woyzeck and Wozzeck - Bü̈hner and Berg. 17/03/2019 tarihinde https://www.academia.edu/25231866/Woyzeck_and_Wozzeck._Büchner_and_Berg adresinden erişilmiştir.

Schmalfeldt, J. (1986). Berg's Wozzeck: Harmonic Language and Dramatic Design. Music Analysis, Vol. 5, (ss. 265-270). 20/03/2019 tarihinde https://www.jstor.org/stable/854188 adresinden erişilmiştir. 
Yener, F. (1992). 100 Opera. İstanbul: Bateş Yayınları.

\section{Kaynakça Bilgisi / Citation Information}

Aytimur, R. G. (2019). Alban Berg'in Wozzeck Operası hakkında tarihsel bir inceleme. OPUS-Uluslararası Toplum Araştırmaları Dergisi, 13(19), 2423-2455. DOI: 10.26466/opus.574108 